\title{
The "We" feeling: \\ Cross-border, cross-language, cross-culture co-operation amongst school librarians who work in Europe
}

\author{
Helen Boelens \\ School librarian and information specialist \\ Kalsbeek College \\ The Netherlands
}

The objective of this paper to help promote a feeling of cross-border, cross-language, cross-culture co-operation amongst school librarians on a European level - a "We" feeling - a feeling of "togetherness". Research shows that school librarians throughout Europe are actively promoting the important work which they are doing, on a national level. By working together on a European level, they can more effectively promote school librarianship in the European Union. The paper also attempts to make colleagues throughout the world more aware of some very specific, European school library problems.

European Union, Library Co-operation, Library Promotion

Introduction

School librarians and information specialists play an important role in the implementation of interdisciplinary information literacy skills in schools throughout digital.

In Europe, school librarians are faced with some specific, very real European problems, for example the diversity of the different national school systems, differences in national (and provincial) legislation related to education, and the large number of national and local languages which are spoken or written. Research evidence shows that school librarians and information specialists are actively promoting their important work at national level, however, cross-border, cross-language, cross-culture co-operation will make their work even more effective and will also help to promote public awareness of this work on a European level.

This paper will, among other things, discuss the recent development of European school library groups. Thanks to the availability of digital technology, these European groups can now communicate in a simple way and exchange information which makes their work more effective.

\section{Background information}

This paper is based on the research carried out at the request of ENSIL (European Network for School Librarianship and Information Literacy). In April, 2003 a group of school librarians and advisors from 8 different countries within Europe formed the 
ENSIL. Since its inception, ENSIL has become a much larger network, with approximately 65 members from 20 different countries in Europe. During ENSIL's inaugural meeting, the delegates expressed an interest in a study which Boelens was carrying out at the Kalsbeek College in Woerden, the Netherlands, which involved the implementation of an information literacy matrix throughout the entire school $(2,600$ pupils). At the Kalsbeek College, the school library and information centre is at the heart of the curriculum and is the place where the introduction of new enquiry based approaches and learning styles are embedded within the curriculum.. Boelens was asked to investigate whether or not a similar matrix could be implemented in secondary schools throughout Europe.

The original research regarding the application of an information literacy matrix on a European basis is described in Boelens' doctoral dissertation, which is expected to be published during 2008. This present paper describes some important conclusions which were reached after reviewing the results of the initial the study.

\section{Analysis and Field Work}

The following actions have been taken in order to find data and also to verify opinions which were recorded in the literature and/or collected during expert interviews.

\section{Questionnaires and/or surveys}

In April 2004, the first ENSIL survey_was sent, in English, to 16 European school library associations. These addresses were provided by the European Network for School Libraries and Information Literacy (ENSIL) and by the International Association of School Librarianship (IASL).

In March 2005, because of a poor return of the original questionnaire, a second ENSIL survey, in English, was sent to National Libraries in 52 European countries, in order to verify addresses of School Library Associations and to ask for further information about school libraries in each specific country.

In August 2007 a third (short) ENSIL Survey was carried out. ENSIL members were asked to verify some conclusions which were reached from earlier ENSIL surveys.

\section{Expert interviews}

Informal interviews were held during the first European Conference on School Libraries, in Wels, Austria, in April 2007. It became apparent that, in some countries, recent changes in school libraries and information centres have taken place. These changes were recorded. Academic experts in the field of information literacy and lifelong learning, from a number of different universities throughout the world were interviewed personally, and also via the internet, and asked for their opinion with regard to a number of hypotheses. Thanks to a combination of research strategies, insight has 
been gained into the state of school librarianship in Europe, as a whole and also per country.

\section{Results from the research which are relevant to this paper}

School libraries and information centres in some European countries are more advanced than others. Some schools have advanced facilities (including superior collections and ICT facilities). Other schools have a smaller budget.

The work carried out by the school library and information specialist not only comprises the traditional goals such as literacy, reading improvement, reading pleasure, searching for and finding information for projects and assignments, or the provision of a friendly place within the school where pupils can study. New goals of the school library and information centre (SLIC), made possible thanks to the introduction of ICT technology, are also very important. They include the stimulation of new forms of learning which now take place in the SLIC, such as learning to learn, individual learning, co-operative learning, enquiry learning and E-learning. Perhaps most important of all is the instruction in interdisciplinary information literacy and lifelong learning skills for both teachers, pupils and parents which takes place in the SLIC. Pupils, teachers and parents learn new skills which prepare them for their roles as citizens in the European society of the 21 st century.

The school librarian and information specialist needs the support of colleagues throughout Europe who find themselves in a similar position. The SLICs may all be different but the goals are similar.

In some countries, the school librarian and information specialist is a qualified teacher and part of the teaching community, with the same benefits and salary. In other countries, this is not the case.

School librarians and information specialists often feel outnumbered. There is often only one school librarian in a large school community which has more than one hundred teachers. They have asked for support for their work.

Some countries have a strong national school library association, others do not.

The situation in the complex information society of the 21 st century is constantly changing. There is a need for constant training and retraining of school librarians and information specialists.

On a national level, more and more school librarians and information specialists are now uniting and actively promoting the important work which they are doing. However cross-border, cross-language, cross-culture co-operation, using traditional and digital forms of communication, will make this work even more effective and will also help to promote public awareness of this work on a European level. 


\section{Problems which are encountered in cross-border communication}

The following problems are encountered in cross-border communication.

\section{Language}

Language plays an important role in communication within Europe. It could be said that the working language of the EU is English. The surveys mentioned above was sent to 52 countries in Europe, including 27 members of the EU, 3 candidate members and 22 other European countries ${ }^{1}$. In these 52 countries, a total of 35 official and national languages are spoken and used. These figures indicate that communication between European school librarians and information specialists may be a problem

During the interviews mentioned above, school librarians were specifically asked if they were able to read English documents, books, papers and other information, and specifically information about developments in school librarianship. The answer was that many of them were unable to do so.

This language problem was also evident with regard to the completion of the English questionnaires (mentioned above). Very little information as been received from countries where French, Spanish and Russian is the official language. The informal interviews identified a problem regarding communication with some School Library Associations in Europe. Even though relatively strong School Library Associations exist in some countries, the questionnaire was not returned to the researcher. The reason for this was a lack of English language skills (or a lack of confidence in these skills) amongst the membership.

\section{School systems}

School systems in Europe differ from one country to the next. In some countries, a national educational policy does not exist. Each province has its own rules and regulations. This means that school systems throughout Europe are extremely diverse. A question which may seem relevant to one country, is completely irrelevant in another.

For example, there are definite differences regarding the legal age when a child may finish his or her education. Also, laws regarding the number of hours of education which a child should receive in one school year vary dramatically. In some poorer countries, children cannot attend school during harvest time - they are needed on the farms.

\section{Description of school library and information centre}

How can a school library be described and who should run this facility? In some cases, a school library and information centre consists of a number of boxes of books which are moved from one classroom to another. Other schools have advanced SLICs

\footnotetext{
${ }^{1} \mathrm{http}$ ://www.nationsonline.org/oneworld/european_languages.htm . Accessed on 6 september 2007.
} 
excellent, modern facilities and a professional school librarian and information specialist who runs this facility.

Some countries have school libraries in primary schools, but very few facilities in secondary schools.

When asked to complete questionnaires, school principals will provide information which indicates that their school library has modern ICT facilities, however, research indicates that, in many cases, these facilities are both limited and outdated.

This diversity makes the European situation more complex. Information about school systems in Europe can be found at Eurydice ${ }^{2}$.

\section{Recent cross-border, cross-language, cross-culture co-operation amongst school librarians and information specialists in Europe}

In April 2007, the first European conference on school libraries took place in Wels, Upper Austria. The topic of the conference, organised by the Library Service for Schools (Bibliotheken-Service für Schulen). was "School Libraries as Places of Learning: no learning without reading". One hundred and thirty school librarians, information specialists and other educators travelled from 18 different countries in Europe to attend the meeting.

During the conference, delegates attended lectures and took part in important discussions which were related to the changes which are taking place in the work carried out by school information specialists since the introduction of ICT and new forms of learning into the schools. The delegates in Wels also discussed the need for new training programmes which would help school information specialists to carry out these new, important tasks.

\section{Important information about school libraries and organisations which promote school librarianship}

Boelens has developed an English reference document, which is available in both traditional and digital form and which is specifically oriented towards school librarianship in Europe. Its purpose is to help promote a feeling of cross-border, crosslanguage, cross-culture co-operation amongst school librarians on a European level - a "We" feeling - a feeling of togetherness. National School Library Associations are invited to translate this document into their own national languages. It focuses on European school library problems and gives suggestions for places where advice can be found. The information can be used by public, government funded schools and their libraries, and also by private or international schools. It assists the reader to access important school library documents:

\footnotetext{
${ }^{2}$ http://www.eurydice.org/portal/page/portal/Eurydice Accessed on 24 January 2008.

${ }^{3} \mathrm{http}: / / \mathrm{www}$.buchzeit.at Accessed on 24 January 2008.
} 
The IFLA/UNESCO School Library Manifesto ${ }^{4}$

This document is now available in 24 European languages. This manifesto defines the mission and goals of the school library or resource centre and the profile of its staff. It emphasises equal opportunities for all learners. School librarians from many different countries throughout Europe can read it, become familiar with it, and use its contents to promote their work.

\section{The IFLA/UNESCO School Library Guidelines ${ }^{5}$}

This document was first published in 2002, to help schools and school librarians to implement the principles expressed in the manifesto. These guidelines were produced to inform decision makers at national and local levels around the world, and to give support and guidance to the school library community. Since their publication, the Guidelines have been translated into 12 European languages.

\section{IFLA School Library Advocacy Kit}

IFLA has also published the School Library Advocacy This document advocates strong school libraries using the IFLA/UNESCO School Library Manifesto and Guidelines and other resources.

\section{IFLA on-line newsletter}

Access to the on-line newsletter which is published by the IFLA section for school libraries and resource centres.

\section{International Association of School Librarianship (IASL)}

In 1971, the International Association of School Librarianship (IASL) was founded. Since 1972, it has held a annual international conferences. Papers have been presented by school librarians and academics from all parts of the world and workshops have been held. These papers are available through the IASL web-site ${ }^{8}$.

The IASL also has a list-serv which allows school librarians from all over the world to communicate with each other.

The IASL Advocacy $\mathrm{Kit}^{9}$ provides countries which do not have a National School Library Association with ideas and procedures for starting one. It also contains a page entitled "School libraries make a difference to student achievement", which contains links to research reports and other documents that show that school libraries make a

\footnotetext{
${ }^{4}$ http://www.ifla.org/VII/s11/pubs/schoolmanif.htm . Last update: 23 March 2007

${ }^{5} \mathrm{http}: / /$ www.ifla.org/VII/s11/pubs/school-guidelines.htm . Last updated: 21 November 2007

${ }^{6} \mathrm{http}: / /$ www.ifla.org/VII/s11/pubs/s11_AdvocacyKit.html Last update: 28 July 2006

${ }^{7} \mathrm{http}: / / \mathrm{www}$. ifla.org/VII/s11/news/school-newsletter45.pdf Accessed on 24 January 2008.

${ }^{8}$ www.iasl-online.org. Accessed on 24 January 2008.

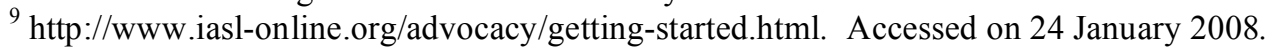


difference to student achievement and that school libraries have a positive impact on student learning.

International School Library Day. Each November, the IASL celebrates International School Library Day. School libraries and other institutions send information about their School Library Day celebrations to the IASL web-page ${ }^{11}$ from all over the world. In $2007 \mathrm{itt}$ contained information from many European schools.

\section{European Network for School Libraries and Information Literacy (ENSIL)}

As mentioned above in the background information, ENSIL was formed in 2003. In December 2007 it had 65 members from 20 countries in Europe. Membership is free of charge. The following statement was adopted by the delegates who were present at the first ENSIL meeting:

Amsterdam Statement on School Libraries and Information Literacy.

International research shows that the quality of students' learning outcomes is greatly enhanced by effective school libraries. All learners in each country of Europe are entitled to quality school library/media centres and services. In order to achieve this, each country in Europe, and the European Union, should adopt and implement the principles of the IFLA / UNESCO School Library Manifesto ${ }^{4}$. ENSIL invites other library and educational organisations throughout Europe to join and contribute to further discussion and action."

ENSIL has a web-site which provides useful information about school libraries throughout Europe, in English and also in other European languages. It also has a useful list-serv (language: English).

\section{Other important information}

Many national school library associations have their own communication tools - a web-site in their own official or national language, a list-serv, a web-page, brochures etc.

There are many more organisations which provide useful information for European school librarians. Below is a list of some of these organisations which may provide useful (usually English) information.

\section{European Council of International Schools (ECIS)}

ECIS is a collaborative network promoting the ideals and best practice of international education ${ }^{10}$. ECIS has a committee for Library and Information Services.

\footnotetext{
${ }^{4}$ http://www.ifla.org/VII/s11/pubs/schoolmanif.htm . Last update: 23 March 2007

${ }^{10} \mathrm{http}: / /$ www.ecis.org/aboutus.asp . Accessed on 22 January 2008.
} 
On the web-page ${ }^{11}$ for this committee, there is a useful list of Resources for Librarians \& Information Specialists in International Schools ${ }^{12}$.

School Library Association (SLA) based in the U.K.

A small amount of the information on the SLA web-site ${ }^{13}$ is written in different European languages. The web-site is a good source of information and resources for school librarians, in Europe and world-wide.

\section{American Association of School Librarians}

The web-site of this organisation ${ }^{14}$ contains a wealth of information for school librarians (in the English language) not only in the USA but throughout the world. Among other things, this site contains excerpts from the internationally acclaimed book Information Power: Building Partnerships for Learning (1998). / American Library Association and Association for Educational Communications and Technology. It also contains the new "Standards for the 21st-century learner" (2007). These important documents support the work of the school library and information specialist.

\section{Association of International Librarians \& Information Specialists}

This association, with its own website ${ }^{15}$, supports the work of different kinds of international librarians and information specialists.

\section{School-libraries net}

This web page provides a list of web pages created by school librarians throughout the world, at public schools and also at private and international schools ${ }^{16}$.

\section{Important European school library projects}

Knowledge and expertise is made available to school librarians and information specialists through long term (European) projects. A simple, unbiased selection of these European projects appears below:

\section{"Rede de bibliotecas escolares" 17}

The 10-year-old Spanish national project "Rede de bibliotecas escolares" (Save the school libraries);

\footnotetext{
${ }^{11} \mathrm{http}: / /$ www.ecis.org/committees/library.htm Accessed on 22 January 2008

$12 \mathrm{http}: / / 158.64 .118 .6 / \mathrm{wr} / \mathrm{user} / \mathrm{library} /$ English/Info\%20specialists/index.htm Accessed on 22 January 2008

${ }^{13} \mathrm{http}: / /$ www.sla.org.uk/ Accessed on 22 January 2008

${ }^{14} \mathrm{http}: / /$ www.ala.org/ala/aasl/aaslindex.htm Accessed on 22 January 2008.

${ }^{15} \mathrm{http}: / /$ ailis.cern.ch/ Accessed on 22 January 2008.

${ }^{16} \mathrm{http}: / / \mathrm{www}$. school-libraries.net Accessed on 22 January 2008.

${ }^{17} \mathrm{http}: / / w w w . r b e . m i n-e d u . p t$ Accessed pon 27 January 2008.
} 
The THEKA Project ${ }^{18}$

The Portuguese Theka Project - the Calouste Gulbenkian Project for Teacher Education to Develop School Libraries - is a project based on co-operation between school libraries, public libraries, the Portuguese Library Association (BAD) and the Gulbenkian Foundation.

\section{The Biblioteche nelle Scuole ("Biblioscuole") Project $\underline{19}$}

This Italian project connects schools and the library world, within a local context. It provides innovative services and grants access to information, thanks to the co-operation and services of the Italian National Library Service (SBN). This national pilot project, which is funded and supported by the Ministry of Education, University and Research, Direzione Generale Servizi Informativi (MIUR-DGSI) and Department of Technology and Innovation (DIT), in collaboration with National Centre for the Union Catalogue (ICCU) and the Ministry of Cultural Heritage (MiBAC), was launched in April 2004. The main aims of the project are:

- to provide a wider access to information;

- to enhance information literacy, and

- to promote reading.

The overall goal is to support lifelong learning, for a continuous cultural development and social inclusion.

\section{$S L A M^{20}, G_{r a n d S L A M}^{21}$ and SLAMIT ${ }^{22}$}

SLAM was a European Community Socrates funded project, with partner schools in 4 European countries.

The GrandSLAM project, a follow-up to the SLAM project, had partner schools from 8 European countries.

SLAMIT uses the experience and outcomes of the SLAM and GrandSLAM projects and seeks to:

- promote the development of school libraries, to become full library and learning resource centres at the heart of the curriculum, and

- introduce new enquiry based approaches and learning styles embedded within the curriculum.

The SLAMIT project now seeks to extend the work of these two earlier successful projects.

\footnotetext{
${ }^{18}$ www.theka.org Accessed on 24 January 2008.

${ }^{19}$ www.biblioscuole.it Accessed on 22 January 2008.

${ }^{20} \mathrm{http}: / / \mathrm{www}$. karmoyped.no/slam/ Accessed on 22 January 2008

${ }^{21} \mathrm{http}: / /$ www.gslam.net/ Accessed on 22 January 2008

${ }^{22} \mathrm{http}: / /$ www.slamit.org/ Accessed on 22 January 2008
} 


\section{The promotion of school librarianship throughout Europe}

School librarians and information specialists throughout Europe are urged to take the following actions.

\section{Publications in official or native languages}

School librarians are urged to ask their National Library Association or National School Library Association to contact the international organisations mentioned above and explain the language problem to them. International organisations are asked to make more information about school librarianship available in the official language of each country. These translated documents can then be distributed to school leaders, local and European politicians, so that they can become aware of the important work which school librarians are doing.

\section{School library law}

Some countries in Europe have a school library law. Others have a school library Bill which is waiting to be presented to the national parliament. A school library law is a law which states that every school should have a properly equipped school library and information centre, run by a professionally trained school librarian. These laws vary from country to country. There are also European countries which have no school library law at all. In some countries, school libraries and education fall under the jurisdiction of the provincial government. While one province or state may have excellent school libraries, others may have none at all. Some individual schools cannot afford to have a school library. It may be left to the principal to decide whether or not the school should have a school library, but in some cases there is just not enough funding to provide a high quality facility.

In countries where there is no school library legislation, the school library association or the national library association can raise this question with local or European politicians. There is sufficient information for this purpose in the IFLA School Library Advocacy $\mathrm{Kit}^{6}$ or on the IASL Advocacy page to support this cause.

\section{European educational databases}

Information about the work of School Libraries and Information Centres in European educational databases. Although there are educational databases which are sponsored by the European Union (EU), they contain very little information about school libraries and their importance in advancing educational achievement in digital Europe. These databases often contain information about ICT technical facilities within the schools, but there is very little information about how (digital) content is administered and/or used by the pupils. Questionnaires sent to teachers may have asked "How often do you use a

\footnotetext{
${ }^{6}$ http://www.ifla.org/VII/s11/pubs/s11_AdvocacyKit.html Last update: 28 July 2006
} 
computer in your lessons" of "How many PC's are available in your classroom?, but important, specific questions such as "How do pupils use ICT to gather information in your lessons?" or "Do they receive instruction in information literacy skills given by a trained person?" are seldom asked.

School librarians are urged to write to their local politicians and ask them to request that specific information about school libraries and information centres and the work of school librarians be included in European databases, per country.

\section{National survey of school libraries}

A national survey of school libraries, per country, can provide important information for school library advocacy and for research about the effectiveness of school libraries in Europe. On-line questionnaires can now be used for these surveys.

\section{Inaccurate information about school librarianship}

School librarians and information specialists are asked to check the data, per country, contained in databases, registers, guides, web-sites etc. This information is often inaccurate or has not been kept up to date. An E-mail or letter can be written with the request that these problems be rectified (via "Contact Us"). There are also links in or to important school library web-sites which do not work. Advise the webmaster of these problems.

\section{Misconceptions}

Some countries take the stand that schools can be serviced by the public library and that school libraries are not necessary. The research indicates that school librarianship is a specific task within the school and needs to be carried out by a person who is specifically trained to do this work.

School leaders sometimes think that "Pupils can find everything they need via Internet". New, current research proves that this is a serious misconception.

\section{Useful tools}

Web 2.0 has provided school librarians with useful tools which make communication easier. Many school library associations have List-Servs or Blogs, in their own national language. School librarians can use this technology to find out what other colleagues are doing and sometimes ask for help or make suggestions.

\section{Recent developments}


Very recently, a number of European colleagues have joined forces to make an application to the European Union for a training programme for school librarians and information specialists. Research has shown that, because of the increasing complexity of the use of ICT in schools, there is an urgent need for trained school librarians and information specialists. Nevertheless very few countries in Europe are still training an adequate number of school librarians, with a teaching accreditation, who will be able to carry out this work. At this point it is not known if funding will be granted.

Research is beginning to show that those countries which have a School Library Law are also still training qualified school librarians and information specialists, with a teaching accreditation. These countries recognise the need for the work of a qualified school librarian and information specialist within the schools.

\section{Conclusions}

The indications are that school librarians from all over Europe, from different cultures and different backgrounds, are joining together to help and support each other in their endeavours. It is to be hoped that this paper will give them encouragement and will provide them with important resources for this purpose.

\section{References}

1. http://www.nationsonline.org/oneworld/european languages.htm . Accessed on 6 september 2007.

2. http://www.eurydice.org/portal/page/portal/Eurydice Accessed on 24 January 2008.

3. http://www.buchzeit.at Accessed on 24 January 2008.

4. http://www.ifla.org/VII/s11/pubs/schoolmanif.htm . Last update: 23 March 2007

5. http://www.ifla.org/VII/s11/pubs/school-guidelines.htm . Last updated: 21 November 2007

6. http://www.ifla.org/VII/s11/pubs/s11_AdvocacyKit.html Last update: 28 July 2006

7. http://www.ifla.org/VII/s11/news/school-newsletter45.pdf Accessed on 24 January 2008.

8. www.iasl-online.org. Accessed on 24 January 2008.

9. http://www.iasl-online.org/advocacy/getting-started.html. Accessed on 24 January 2008.

10. http://www.ecis.org/aboutus.asp . Accessed on 22 January 2008.

11. http://www.ecis.org/committees/library.htm Accessed on 22 January 2008

12. http://158.64.118.6/wr/user/library/English/Info\%20specialists/index.htm Accessed on 22 January 2008

13. http://www.sla.org.uk/ Accessed on 22 January 2008

14. http://www.ala.org/ala/aasl/aaslindex.htm Accessed on 22 January 2008.

15. http://ailis.cern.ch/ Accessed on 22 January 2008.

16. http://www.school-libraries.net Accessed on 22 January 2008.

17. http://www.rbe.min-edu.pt Accessed pon 27 January 2008.

18. www.theka.org Accessed on 24 January 2008.

19. www.biblioscuole.it Accessed on 22 January 2008.

20. http://www.karmoyped.no/slam/ Accessed on 22 January 2008

21. http://www.gslam.net/ Accessed on 22 January 2008

22. http://www.slamit.org/ Accessed on 22 January 2008

\section{Biographical note}


Helen Boelens is the Chief Librarian, Kalsbeek College, Woerden, the Netherlands. She is also a $\mathrm{PhD}$ research student at the School of Lifelong Learning and Education, Middlesex University in London. She is also a founding member of the European Network for School Libraries and Information Literacy (ENSIL).

\section{Statement of Originality}

This statement certifies that the following paper is based on original research undertaken by the author and that the paper was conceived and written by the author alone. All information and ideas from other is referenced.

Helen Boelens

15 May 2008 